Левчук, Ірина, і Руденко, Ірина. «Гендерний вимір кінесики як домінанти невербальної комунікації у творчості Володимира Лиса». Лінгвостилістичні студії, вип. 12, 2020, с. 97-106.

Levchuk, Iryna, and Rudenko, Iryna. "Kinesics Gender Dimension as a Dominant of Nonverbal Communication in the Volodymyr Lys's Works". Linguostylistic Studies, iss. 12, 2020, pp. 97-106.

УДК 811.161.3'373:821.161.3.09-1

https://doi.org/10.29038/2413-0923-2020-12-97-106

\title{
ГЕНДЕРНИЙ ВИМІР КІНЕСИКИ ЯК ДОМІНАНТИ НЕВЕРБАЛЬНОЇ КОМУНІКАЦІЇ У ТВОРЧОСТІ ВОЛОДИМИРА ЛИСА
}

\author{
Ірина Левчук \\ Східноєвропейський національний університет імені Лесі Українки, \\ Луцьк, Україна \\ Ірина Руденко \\ Східноєвропейський національний університет імені Лесі Українки, \\ Луцьк, Україна
}

У статті досліджено специфіку репрезентації кінесичних засобів комунікації в романі Володимира Лиса «Соло для Соломії»; вирізнено основні субкатегорії: мімічні вирази обличчя, жести, рухи тіла, пози. Зосереджено увагу на гендерній диференціації компонентів кінесики в художньому тексті, встановлено домінування жестів 3 адапторами голова та рука для актуалізації жіночої комунікативної поведінки. Встановлено прагматичну зумовленість добору одиниць вербалізації кінесики, їх образності особливостями психологічного портретування персонажів і тематикою твору.

Ключові слова: невербальна комунікація, кінема, вербалізація, жіноча комунікативна поведінка, чоловіча комунікативна поведінка, художній текст.

\section{KINESICS GENDER DIMENSION AS A DOMINANT OF NONVERBAL COMMUNICATION IN THE VOLODYMYR LYS'S WORKS Iryna Levchuk \\ Lesya Ukrainka Eastern European National University, Lutsk, Ukraine} Iryna Rudenko

Lesya Ukrainka Eastern European National University, Lutsk, Ukraine

The article highlights the specific features of the kinesics means of communication in the novel by Volodymyr Lys Solo for Solomiya. The author distinguishes the basic categories of kinesics explication in the novel, namely facial expressions, gestures, body movements, postures. The author uses mainly verbs to pout, to twitch, to inflate, to cover, to whisper, to kiss, to put, to stir, to wipe, to rub, to bite, to chew for a detailed description of the kinesics parameters of nonverbalism expressed by kinemes of lips, mouth. Often, semiotically significant movements in a literary work are detailed by identifiers (adjectives and adverbs).

The study has revealed that the kinesics component of nonverbalism in the text is mostly actualized in the constructions with adapters of the upper body: head (ear, eye, pupil, forehead, cheek, nose, chin, tongue, tooth, hair, face, temple, forehead), neck, shoulder, chest, heart, belly, side, waist, nape, back, hand (elbow, wrist, fist, finger, palm, nail) and lower body: leg (thigh, knee, calf).

() Левчук I., Руденко І., Східноєвропейський національний університет імені Лесі Українки, 2020.

Це стаття відкритого доступу на умовах CC BY-NC 4.0 
In the focus of attention is gender differentiation of components of kinesics in the literary text. Dominant are typical female gestures and poses: hands to the sides (demonstration of militant intentions, conflict), clap your hands (manifestation of joy), put the head on the shoulder (tenderness), blink the eyes (a sign of confusion), put a finger on the lips (call to silence), cover the mouth with a hand (restraint in the manifestation of the reactions), hide the face in a pillow or press a face against the pillow (expressing shyness), wave the hips, beckon with a finger, scratch with a fingernail (display of flirtation, coquetry), stomp a foot (manifestation of dissatisfaction, aggression), bend the knees almost under the chin (protective posture), etc.

The author often uses different types of gestures and movements without adapters to describe the nonverbal communication of the characters: a) gestures of a tactile nature; b) gestures and movements caused by the inner state, as a fleeting expression of emotions; c) gestures to indicate a situationally forced action, etc. Verbalizing female kinetic behavior, V. Lisi uses gestures, movements, reactions of the metaphorical type.

The facial expression has clear gender features among the indicators of internal emotional states used by the author to portray the characters. Naturally, women are more likely to express their emotions and show them openly. In the analyzed text, such mimicry means of non-verbalisation as a smile is, definitely, gender differentiating.

Selection of the units of kinesics verbalization and the means of their imagery intensification in the literary text is predetermined by peculiarities of the psychological portrayal of characters and the theme of the work.

Key words: nonverbal communication, kinesics, verbalization, female communicative behavior, male communicative behavior, artistic text.

Вступ. Протягом останніх років спостерігаємо зацікавленість лінгвістів дослідженнями невербальних засобів комунікації, що зумовлено усвідомленням вагомості частки невербаліки в особистісному спілкуванні. Ученими встановлено, що «різноманітні невербальні сигнали <...> несуть від 60 до 80 \% інформації» (Бацевич 59). Зокрема, мовознавці сфокусували увагу на розмежуванні понять «невербальна комунікація», «невербальне спілкування», «невербальна поведінка», а також типологї невербальних засобів (Бацевич; Ковалевська; Крейдлін; Солощук). Водночас дослідники активно вивчають особливості функціонування невербаліки в процесі комунікації (Гавриш; Ковалинська; Серякова; Ставицька), специфіку репрезентації несловесних елементів засобами мови (Дука; Осіпова; Ставицька) тощо. Посилений інтерес до відображення невербальної поведінки людини в писемних текстах, передусім у художній літературі, спричинив виокремлення дискурсивного аналізу невербаліки (Гармаш; Корнєва; Космеда, Карпенко, Осіпова, Саліонович, і Халіман; Осіпова; Солощук). Однак специфіка актуалізації невербальних засобів комунікації в різних дискурсах вимагає більш грунтовного вивчення. Т. Осіпова слушно зауважує: «дискурсивна методика знаходиться на шляху становлення й потребує відповідного термінологічного забезпечення, зокрема терміносполуки «вербалізація невербаліки» як базової» (109). Саме необхідність комплексного дослідження особливостей відтворення невербаліки в художніх текстах, співвідношення вербального й невербального кодів зумовлює актуальність нашої роботи. 
Мета дослідження - проаналізувати гендерні параметри особливостей вербалізації кінесики як домінанти невербальної комунікації в художньому тексті Володимира Лиса. Зауважимо, що в попередній розвідці ми розглянули специфіку актуалізації акустичного складника невербаліки (Левчук, Руденко).

Матеріал і методи дослідження. Матеріалом роботи слугував роман «Соло для Соломії» Володимира Лиса.

У дослідженні використано метод суцільної вибірки для фіксації мовних одиниць на позначення невербальних кодів кінесики в художньому тексті; описовий метод для систематизації фактичного матеріалу й встановлення домінант; метод контекстуального аналізу - для з'ясування семантичної структури опорних лексем i типології їx сполучуваності.

Результати дослідження та дискусія. Аналізуючи вагомість невербальних кодів у спілкуванні, науковці слушно акцентують увагу на їх багатоманітності, вирізняючи: 1) паралінгвістику (тембр голосу, діапазон, тональність); 2) кінесику (різні жести та жестові рухи); 3) гаптику (мову дотиків і тактильну комунікацію); 4) окулесику (мову очей і візуальну поведінку); 5) проксеміку (просторову організацію спілкування); 6) системологію (мову одягу, прикрас, зачісок); 7) гастику (знакові та комунікативні функції їжі та напоїв, пригощання); 8) ольфакторику (мову запахів) (Ставицька 314). Домінувальними складниками цієї системи варто розглядати одиниці кінесики, що «охоплює кілька субкатегорій: вирази обличчя (рухи м'язів обличчя); жести (рухи рук і пальців); рухи тіла (рухи рук, ніг, торсу); пози (розташування тіла, яке може бути ідентифіковане за умов відсутності рухів тіла)» (Ставицька 322 ).

У художньому творі письменник, характеризуючи невербальну поведінку героїв, намагається детально описати жести, рухи тіла та пози. Як стверджує Л. Корнєва: «Створюючи своєрідний невербальний контекст, кінеми семантично модифікують і завершують повне чи зредуковане вербальне висловлювання та виявляють у ньому додаткові смисли» (117).

Зокрема, у романі «Соло для Соломії», фіксуємо такі жести й рухи, пов'язані з кінемами губи (вуста/ уста), рот: закопилювати губки, сіпнулася нижня губа (семантичне значення яких гніватися, ображатися, характерне переважно для жінок, дівчат, дітей); надути губки (здебільшого маркується як дитячий, проте як фемінний використовується для експлікації кокетування, імітації образи); губи стали тремтіти, затремтіли губи (характеризує сум'яття, збентеження, біль); кусати губи (семантика фразеологізму «виявляти почуття досади, образи, заздрощів і т. ін.» (Фразеологічний 1: 407)), закусити/ прикусити губу, пожувати нижньою губою, підтиснути губи; затулити долонею/ рукою рота, міцно стискати губи й зуби; витерти губи (жест відбувається після поцілунку); уста шепочуть молитву, губами ворушити тощо. 
Окремо варто вирізнити засоби вербалізації тактильної поведінки персонажів із допомоги кінем, як-от: торкнутися вустами його лоба, губи злилися з ї̈ вустами, заціловані і розпухлі губи, обцілувати губи, покласти на губи пальця, затулити їй поцілунком рота, тулити губи до вуха, цілуватися губами (жести, притаманні закоханим, або ж відбуваються в інтимній ситуації). Здебільшого ініціатором такої невербальної поведінки є чоловіки: «Він затулив її вуста поцілунком. Тоді став обціловувати щоки, лоба, очі, шию» (Лис 232); «Спробував поцілувати наостанок. Ухилилася. Все ж щмокнув у щоку» (Лис 345).

Прикметно, що для детального опису кінесичних параметрів невербаліки, увиразнених кінемами губи, уста (вуста), рот, автор використовує переважно дієслова: закопилити, сіпнутися, надути, затуляти, шептати, цілувати, класти, ворушити, витирати, терти, кусати, жувати. Однак нерідко семіотично вагомі рухи в художньому творі деталізовують ідентифікатори (переважно прикметники та прислівники), наприклад: «Соломія таки торкнулася розпашілими вустами його лоба» (Лис 22); «<..> пригасила прикушуванням геть зацілованих і аж розпухлих губ тихенький смішок» (Лис 96).

Серед жіночих та чоловічих жестів і рухів, пов'язаних із верхньою частиною тіла, у тексті простежуємо їх функціонування з адапторами:

1) голова: покласти руку на голову, підвести голову, погладити по голові, вертіти головою, схилити голівку, на коліна покласти голівку, торкнутися ї̈ голови, опустити голову, закивати головою, захитати головою, задерти голову, повернути голову, битися головою об стіну, закидати руки над головою, головою бити в носа, обхопити голову руками, втягти голову в плечі, кивати головою; а) вухо: за вухо схопити, нахилятися до вуха, затулити вуха долонями, тулити губи до вуха; б) око: кліпати оченятами, очі блиснули, підвести очі, опускати очі, підводити очі, примружити око, зиркнути оченятами, зводити оченята, заплющити очі, терти око, злякано водити очима, розплющувати очі, глипнути оком, витріщити очі, очима блим-блим, обціловувати очі; в) зіниця: зіниці розширилися; г) лоб: торкнутися вустами лоба, лоба рукавом витирати, руку на лоба покласти, притулитись лобом, погладити по лобі, витирати долонею лоба, обціловувати лоба, лобом бити в носа, цьомнути в лобик; г) щока: щокою тулитися, тернути щоку рукою, щока сіпнулася, щокою об щоку тернутися, обцілувати щоки, вдарити по щоках, цмокнути в щоку, підклавши руку під щоку, поцілувати в щоку, торкатися щоки; д) ніс: в плече носиком ткнутися, шморгати носом, до носа підносити, бити в носа; е) підборіддя: взяти пальцями за підборіддя, підібгавши під підборіддя колінки; є) язик: язика показати; ж) зуб: цокати зубами, стиснути зуби, зубами заскреготати; з) волосся: гладити волосся, вчепитися у волосся, за волосся підтягти, обцілувати волосся; и) лице: закрити лище руками, бити в лище, в подушку занурити лище, притискатися лищем до подушки, на лище бризнути, сховати лище в 
подушку; і) скроня: розтирати скроні; ї) чоло: гладити рукою по чолі, чоло нахмурити, поцілувати в чоло;

2) шия: обцілувати шию, руки, сплетені довкола шиї;

3) плече: в плече носиком ткнутися, за плече торкнути, тримати за плече, межи плечі тузнути, плечиком здвигнути, схопити за плечі, до плеча притулитися, припадати до плеча, гладити плечі, торкнутися плеча, рука з плеча сповзла, поцілувати в плече, за плечі трясти, плечі трусяться, брати за плечі, втягти голову в плечі, плечі здригалися, торснути за плече;

4) груди: ткнути пальщем у груди, хапатися за груди, тиснути до грудей, вдарити в груди, тулити до грудей, припасти до грудей, тертися грудьми, за груди вхопитися, кинутися кулачками у груди, впасти на груди;

5) серце: за серце схопитися;

6) живіт: руки тягнути до живота, цілувати живота;

7) бік: бити кулачком в бік, руки в боки, під бік штурх;

8) поперек: за поперек схопитися;

9) потилиця: почухати потилицю;

10) спина: притулитися спиною до дверей / до стіни, рука шарпнулася за спину, по спині кулаком;

11) рука: до руки торкнутися, брати руку / на руки / за руку / до рук, рукою махати, покласти руку на голову, провести руками, в руку тицьнути, схопити руками, підхопити під руки, руку підняти, простягати руку, вдарити руками по колінах, гладити рукою по чолі, рука шарпнулася за спину, покласти на голову руку, сплеснути руками, вдарити по руці, до рук ткнути, хапати за руку, шарпати за руку, втиснути чарку в руку, руками розмахувати, руку стискає рука, змахнути рукою, руки в боки, тернути щоку рукою, руки тяглися до живота, руку на лоба покласти, рука розстебнула кожушка, закрити лище руками, задрижала рука, розминати руки, прийняти руку, ручкі за голову, ручкою помахувати, ручкою мах-мах, руки трусяться, стиснути руками голову, рука до руки потяглася, назад руку відсмикнути, рука з плеча сповзла, струсонути рукою, рукою дати штурхана, руку поцілувати, з піднятими руками, спинити порух руки, гладити руку, руки розкидати, руки звисають, ручкою поцілунок послати, руки у кулачки скласти, підкласти руку під щоку, на руках нести/ принести, руками обхопити, затулити рукою рота, хапати за руки-ноги, закидати руки над головою, простягти і опустити руку, руки підняли плаття, руки, сплетені довкола шиї, рвонути за руку, затуляти рукою рота, підперти рукою праву щоку, ловити ручками мухизірочки, рукою за рукав торкнути, руки трусяться, підтримувати під руку, колихати на руках, потерти руки, зачерпати рукою-човником, рука тяглася до телефону, показувати руками, вивести рукою; а) лікоть: звестися на лікті; б) зап'ястя: стиснути зап'ястя, торкатися зап'ястя; в) кулак: розтулити стиснуті кулачки, грюкнути кулаком, 
бити кулачком в бік, бити кулаками, терти кулачком око, кулачком межи плечі тузнути, руки у кулачки скласти, кулачками у груди, по спині кулаком трах, тримати у затиснутому кулаці; г) палець: стиснути пальчики, пальчики загинати, вказівного пальця зводити / піднімати, вкусити за палець, тремтять пальці, пальчиком потерти, пальці гладити, пальцем поманити, ткнути пальцем у груди, взяти пальцями за підборіддя, погрозити пальцем, пальцями торкнутися, пальцями долоню пошкрябти, затуляти пальцями, пальці до грудей притиснути, покласти на губи пальця, на кінчиках пальців ступити вбік, вколоти пальця, виставити пальця, пальцем кивати, обціловувати пальці, зімкнути /розімкнути пальці обох рук, пальці розтислися; ґ) долоня: $\boldsymbol{y}$ долоні / долоньки плескати, сплеснути долоньками, бити лінійкою по долонях, простягти долоні, долонею сльозини визбирувати, пальцями долоню пошкрябти, долонею сльози витерти, губи долонею витирати, долоню до грудей притиснути, витерти ребром долоні сльози, затулити вуха долонями, гладити пальці й долоні, витирати долонею лоба, витерти губи тильним боком долоні; д) ніготь: нігтиком пошкрябти.

Дослідивши засоби актуалізації кінесичної поведінки персонажів, що пов'язані з верхньою частиною тіла, простежуємо домінування жестів 3 адапторами голова та рука. Більшість із них характеризує жіночу невербальну поведінку. Зокрема, як типово жіночі оцінюємо жести: руки 8 боки (демонстрація войовничих намірів, конфліктності), сплеснути долоньками (прояв радості), припадати до плеча (вияв ніжності), кліпати оченятами (ознака розгубленості), соромливо опустити очі (маніпуляція 3 семантикою нещирості, брехні), покласти на губи пальщя (заклик до мовчання), затулити рукою рота (стриманість у вияві реакцій), сховати лище в подушку та притискатися лищем до подушки (маркування сором'язливості), пальцем поманити та нігтиком пошкрябти (вияв загравання, кокетства) тощо.

Розмежовуючи типові вияви жіночої та чоловічої кінесичної поведінки, В.Лис намагається водночас створити динамічні портрети персонажів, передати почуття та емоції героїв. Порівняймо: «Дядьки чухали лоби й потилиці - не хотілося з нажитим поліщуцьким горбом сяким-таким добром розлучатися, а їхні жсінки крадькома, а то й не криючись, витирали сльози й шептали давні замовляння од наглої напасті» (Лис 195).

Значно меншою мірою представлені в тексті жести, пов'язані $\mathbf{3}$ нижньою частиною тіла, з адапторами:

1) нога: на ноги звестися, тупнути ніжскою / ногами, ноги розставити, відсунути кота ніжскою, ногою турнути кота-насмішника, переступати з ноги на ногу, ноги дрижать, двигнути ногами, копнути ногою / ногами, вдарити ногою, ноги підігнулися, цілувати ноги, хапати за руки-ноги, підкосилися ноги, брати в руки ногу, підставити ногу; а) стегно: стегнами хилитати; б) коліно: стати на коліна, звестися / 
підвестися з колін, вдарити руками по колінах, схилити / покласти голівку на коліна, опуститися на коліна, на колінах поповзти, опустити / опуститися на коліна, підібгати мало не під підборіддя колінки; в) литка: вдарити у литку.

Жіночий стиль кінесичної поведінки вирізняють такі жести, як тупнути ніжкою, вдарити руками по колінах, стегнами хилитати, підібгати мало не під підборіддя колінки тощо. Зокрема, автор нерідко коментує невербаліку персонажів, акцентуючи увагу на віковій специфіці жестів і поз, як-от: «Варка спала, підклавши руку під щоку, геть подитячому, і так само підібгавши мало не під підборіддя гострі колінки» (Лис 215).

Частотно в аналізованому тексті простежуємо жести та рухи без адапторів, зокрема: жести тактильного характеру - підходити і гладити, горнутися до чоловіка, поцілувати, обцілувати, погладити ледь-ледь, підсадити на коня, в обійми схопити, обняти, тиснути до себе, пригорнути, притискати до себе, притиснути так, що душно стало; жести та рухи, викликані внутрішнім станом, як швидкоплинний вияв емоцій - ледь відсахнутися, тремтіти, спалахнути (почервоніти), почати танцювати (як вияв радості), крутнутися, зітхнути, відмахнутися, затруситися; жести на позначення ситуативно вимушеної дії - нагнутися / нахилитися, покірно опуститися, повернутися, опуститися на стілець / на долівку / на лавочку, піднятися, нахилитися, вдарити, низько / злегка вклонитися, пригнутися, підводитися, обтерти, надкусити, одвернутися, прихилитися до неї, простягти рушника, ближче посунутися, присісти навпочіпки, податися назад, розв'язати черевики тощо.

Семіотично значущими для декодування комунікативної поведінки персонажів виступають жести, рухи, реакції метафоричного типу, хоча кількісно їх значно менше в тексті, наприклад: посмішка торкнулася кутиків вуст, паморочиться / закрутилася голова, око пропекло наскрізь, дико водячи очима, очі сяяли, очі на лоба полізли, щоки спалахнули / запашіли, щоки стали бурячковими, вогонь з печі на щоки перебирався, блиснув золотим зубом, на лище хтось вилив цілеє відро червоної фарби, лице пополотніло, кидалася на шию, впала на груди, мороз по шкірі пробіг та інші. Прикметно, що здебільшого шляхом метафоризації письменник актуалізує кінесичну поведінку жінок. Очевидно, ця закономірність зумовлена не тільки гендерною специфікою жестів, поз і рухів, але й тематикою тексту, адже в романі «Соло для Соломї̈» В. Лис розповідає історію жінки, вписуючи ї̈ в контекст XX століття. Детальний опис психічних станів героїнь, емоцій, почуттів, типової невербальної поведінки уможливлює створення більш реалістичного художнього образу.

Варто зауважити, що виразну гендерну специфіку серед індикаторів внутрішніх емоційних станів, якими послуговується автор для портретування героїв, має вираз обличчя. Природньо, що жінки більш схильні виявляти свої емоції й відкрито демонструвати їх. Зокрема, такий 
мімічний засіб невербаліки, як посмішка в аналізованому тексті гендерно диференційований (з увиразненням залежно від віку героїв): дитяча (тилько всміхнулася, посміхнулася), дівоча (всміхається Руфина, змійкоюсмішечкою на вустах, усміхнулася, посміхалася, з усмішечкою), жіноча (ледь-ледь всміхаючись, посміхнулася, всміхнулася, посмішка стала ширшою i насмішкуватішою, гірка усмішка лягла), чоловіча (посміхнувся, усміхнувся) та стареча (всміхнулася баба, посміхнулася, усміхнувся й зітхнув). Серед мовних репрезентантів цього мімічного складника комунікації здебільшого представлені дієслова сміятися, всміхатися/ усміхатися, посміхатися тощо. Однак зрідка автор використовує атрибутивні лексеми для деталізованого опису емоційного стану персонажів, як-от: «<..> посміхнулася трохи сумовито Соломія» (Лис 315); «<...> тільки посміхнулася загадково. І щасливо. Тричі щасливо. Сто й десять разів» (Лис 300). Водночас письменник декодує значення посмішки персонажів для читача, використовуючи образні елементи: «Руфина-Раїса посміхнулася. 3 тої усмішки вилетіла велика сіра птаха й закаркала» (Лис 187); «А він розтягає усмішку аж за вуха» (Лис 295); «Соломія зирнула на нього, гірка усмішка лягла, наче тінь на його вуста» (Лис 343).

Висновки та перспективи досліджень. Отже, кінесика в романі В.Лиса «Соло для Соломії» з-поміж актуалізованих невербальних компонентів комунікації домінує. Вона репрезентована описами мімічних виразів обличчя, жестів, рухів тіла та поз, що найчастіше доповнюють вербальний рівень, уточнюють інформацію, створюючи єдиний художній простір комунікації. Кінесичний компонент невербаліки в тексті здебільшого експліковано через конструкції з адапторами верхньої частини тіла: голова (вухо, око, зіниця, лоб, щока, ніс, підборіддя, язик, зуб, волосся, лище, скроня, чоло), шия, плече, груди, серце, живіт, бік, поперек, потилиця, спина, рука (лікоть, зап'ястя, кулак, палець, долоня, ніготь) та нижньої частини тіла: нога (стегно, коліно, литка). Зафіксовані вербалізатори міміки, жестів, поз, рухів тіла переважно маркують жіночу комунікативну поведінку, увиразнюючи психологічні портрети персонажів.

Перспективи дослідження вбачаємо в порівнянні гендерних параметрів мовної репрезентації кінесичних засобів комунікації в інших текстах В. Лиса.

\section{Список використаної літератури}

Бацевич, Флорій. Основи комунікативної лінгвістики. Київ, 2004.

Гавриш, Марія. «Аналіз невербальної поведінки комунікантів у ситуаціях ситуативного домінування». Актуальні проблеми філології та перекладознавства, вип. 16, 2019 , с. 25-30.

Гармаш, Елена. «Гендерные особенности невербальной коммуникации в художественном тексте». Ученые записки Таврического национального университета им. В. И. Вернадского. Серия: Филология. Социальные коммуникации, т. 24 (63), № 4, ч. 2, 2011, с. 226-30. 
Дука, Марія. «Мовна репрезентація невербальних засобів комунікації як об’єкт навчання майбутніх філологів читання творів англомовної художньої літератури». Вісник Київського національного лінгвістичного університету. Серія: Педагогіка та психологія, № 22, 2013, с. 144-51.

Ковалевська, Тетяна. Комунікативні аспекти нейролінгвістичного програмування. Одеса, 2001.

Ковалинська, Інна. Невербальна комунікація. Київ, 2014.

Корнєва, Людмила. «Мовна репрезентація невербальної поведінки героїв художнього твору та її роль у тексті». Філологічні науки, вип. 1 (7), 2011, с. 114-21.

Космеда, Тетяна, Карпенко, Наталія, Осіпова, Тетяна, Саліонович, Людмила, і Халіман, Оксана. Гендерна лінгвістика в Україні: історія, теоретичні засади, дискурсивна практика. Харків; Дрогобич, 2014.

Крейдлин, Григорий. Невербальная семиотика: Язык тела и естественный язык. Москва, 2002.

Левчук, Ірина, і Руденко, Ірина. «Гендерні параметри актуалізації акустичних засобів комунікації у творчості Володимира Лиса». Лінгвостилістичні студії, вип. 9, 2018, с. 91-99, doi:10.29038/2413-0923-2018-9-91-99.

Лис, Володимир. Соло для Соломії. 2-ге вид. Харків, 2015.

Осіпова, Тетяна. «Невербальні засоби комунікації: комплексна методика опису й лексикографування». Studia Ukrainica Posnaniensia, вип. 6, 2018, с. 107-13.

Серякова, Ирина. Невербальный знак коммуникации в англоязычных дискурсивных практиках. Киев, 2012.

Солощук, Людмила. Вербальні і невербальні компоненти комунікації в англомовному дискурсі. Харків, 2006.

Ставицька, Леся. Гендер: мова, свідомість, комунікація. Київ, 2015.

Фразеологічний словник української мови, уклад. В.М.Білоноженко, В. О.Винник, I. С. Гнатюк та ін. У 2 кн. 2-ге вид. Київ: Наукова думка, 1999.

\section{References}

Batsevych, Florii. Osnovy komunikatyvnoi linhvistyky. Kyiv, 2004.

Gavrysh, Mariia. "Analysis of non-verbal behavior of communicants in context of situational dominance". Current issues of linguistics and translation studies, iss. 16, 2019, pp. 25-30.

Garmash, Elena. "Gender features of nonverbal communication in the works of fiction". Scientific Notes of Taurida National V.I. Vernadsky University. Series: Filology. Social communicatios, vol. 24 (63), no. 4, part 2, 2011, pp. 226-30.

Duka, Mariia. "The verbal representation of non-verbal signals as the object of teaching future philologists to read modern English fiction". Visnyk of Kyiv National Linguistic University. Series Pedagogy and Psychology, no. 22, 2013, pp. 144-51.

Kovalevska, Tetiana. Komunikatyvni aspekty neirolinhvistychnoho prohramuvannia. Odesa, 2001.

Kovalynska, Inna. Neverbalna komunikatsiia. Kyiv, 2014.

Kornieva, Lyudmila. "Speech representation of non-verbal behavior of the heroes of the literary work and its role in the text". Philological Sciences, iss. 1 (7), 2011, pp. 114-21.

Kosmeda, Tetiana, Karpenko, Nataliia, Osipova, Tetiana, Salionovych, Liudmyla, and Khaliman, Oksana. Henderna linhvistyka v Ukraini: istoriia, teoretychni zasady, dyskursyvna praktyka. Xarkiv; Drohobych, 2014.

Krejdlin, Grigorij. Neverbal'naja semiotika: Jazyk tela i estestvennyj jazyk. Moskva, 2002.

Levchuk, Iryna, and Rudenko, Iryna. "Gender Parameters of Acoustic Means of Communication Actualization in the Works of Volodymyr Lys". Linguostylistic Studies, iss. 9, 2018, pp. 91-9. doi:10.29038/2413-0923-2018-9-91-99/

Lys, Volodymyr. Solo dlia Solomii. $2^{\text {nd }}$ ed. Kharkiv, 2015. 
Osipova, Tetiana. "Non-verbal means of communication: new complex method of description and registering in dictionaries". Studia Ukrainica Posnaniensia, iss. 6, 2018, pp. 107-13.

Serjakova, Irina. Neverbal'nyj znak kommunikacii $v$ anglojazychnyh diskursivnyh praktikah. Kiev, 2012.

Soloshchuk, Liudmyla. Verbalni i neverbalni komponenty komunikatsii $v$ anhlomovnomu dyskursi. Kharkiv, 2006.

Stavytska, Lesia. Hender: mova, svidomist, komunikatsiia. Kyiv, 2015.

Frazeolohichnyi slovnyk ukrainskoi movy, edited by V. M. Bilonozhenko, V. O. Vynnyk, I. S. Hnatiuk et al. 2 vols. $2^{\text {nd }}$ ed. Kyiv: Naukova dumka, 1999.

Стаття надійшла до редколегії 07.11.2019 